\title{
Women's Participation in Local Government: An Assessment of Enhancers and Inhibitors in the Komenda-Edina-Eguafo-Abirem Municipality
}

\author{
Raymond Kwasi Boasinke ${ }^{*}$
}

\begin{abstract}
The participation of women in local government is one of the burning governance issues in the world today. Such participation is expected to serve as a springboard to propel women to participate at the national level. However, an analysis of women's participation in local government reveals that women are grossly underrepresented. This study assessed the factors that enhance and inhibit women's participation in local government as elected representatives in the Komenda-Edina-Eguafo-Abirem Municipality of the Central Region of Ghana. The qualitative approach was used to conduct in-depth interviews using a census of all the elected past and present assembly members in the Municipality. The study revealed that women's participation at the household level, training and education by Non-Governmental Organizations, and cordial working relationship with male colleagues in local government were the main enhancers of women's participation in local government. The inhibiting factors revealed by the study included financial constraints, unreasonably high expectations, and the non-cooperative attitudes of community members. It is recommended that women and girls be made an integral part of household decision-making. Women who contest local elections should be supported financially. The NGOs that ran programs to empower women to participate in local government should be encouraged and supported.
\end{abstract}

Keywords: Women, Participation, Local Government, Assembly Members

\section{Introduction}

Women's participation in politics is consistent with the tenets of natural justice or democracy, and it is also an excellent avenue for their interests and views to be enshrined into national policies. It has been argued that as long as politics does not consider women's opinions on the same footing as men in shaping public policies and governance, human society will continually run a flawed system of governance (Nwagbara, 2009). Recognizing the importance of women's participation in politics and all other facets of life has led many countries and organizations to incorporate gender equality into their policies and programs. Both the Millennium Development Goals and Sustainable Development Goals devoted significant attention to gender equality and empowerment issues. For example, the European Union has enshrined gender equality in the EU Treaties and the EU Charter of Fundamental Rights (European Union, 2013).

\footnotetext{
* University of Cape Coast, Cape Coast, Ghana. Email: raymond.boasinke@ucc.edu.gh
} 


\section{PanAfrican Journal of Governance and Development, Vol. 2, No. 2, August 2021}

In Ghana, there have been attempts to increase the number of women in politics at both the national and local levels. The earliest attempt to give women a sound footing in politics at the national level started immediately after independence. It culminated in the introduction of a quota system for women. Under this system, ten special seats were reserved for women in the National Assembly (Tamale, 1999). The quota system was to serve as a foundation upon which greater participation of women in politics and public life was to be built (Allah-Mensah, 2005). The CPP government at the time also appointed women as District Commissioners and had one woman as a deputy minister (Tsikata, 1989; Manuh, 1991). This initial springboard for greater participation of women in Ghana was truncated by the 1966 coup and the subsequent coups and counter-coups. Although successive governments have made some attempts at enhancing women's participation, the Provisional National Defence Council (PNDC) attempted to address the issue from the grassroots level. This was mainly done through the introduction of a new decentralization system in 1988. This decentralization policy contains provisions such as the non-partisan local government system, the freedom to use the local language for the assembly's business, and the discretion in creating additional sub-committees (Offei-Aboagye, 2000) that are aimed at facilitating women's participation in local government. However, an examination of women's participation in local government in Ghana reveals that the percentage of elected women in local government is still very low. The percentage of women who have been elected into local government since 1994 has been 6 percent on average (Boateng \& Kosi, 2015). The slow progress in women's participation in spite of all the global and national efforts could be appreciated in the words of Schwanke (2013:8) "The structural, prejudicial, and discriminatory hurdles these women face are often subtle and misunderstood, creating a complex, pervasive, and multi-faceted labyrinth that thwarts any progress they may make."

\section{Statement of the Problem}

Available countrywide data on women's performance in the local level elections in Ghana suggests that women have only made marginal gains over the years. An analysis of the data on the number of elected women from 1994 to 2015 shows that in terms of percentage, women's representation nationwide has averaged less than 10 percent of the total number of elected members. The data show that only in 2006 that the number of elected women in local government nationwide went beyond 10 percent (Boateng \& Kosi, 2015). This data puts Ghana's

efforts at enhancing women's participation in politics at the local level in a rather sobering 
context. This is especially so because the framers of the local government act intended to use the participation of women in local government as a springboard to propel more women into national politics.

The Komenda-Edina-Eguafo-Abirem (KEEA) municipality in Ghana's Central Region, where this study was carried out, is not an exception to this national problem of poor representation of women in politics at the local level. For instance, in 2006, the Municipality had six elected women, but this dropped from six in 2006 to three in 2010. It also represented a reduction of 50 percent. This issue was even more crucial because none of the previously elected women who served their four-year term in 2006 was re-elected in 2010. Of the five women candidates who contested the 2015 local elections, none was elected. In the 2019 local elections, no woman was elected to represent an electoral area in all the 37 electoral areas in the Municipality. This means that the Municipality has not had an elected female representative since 2015. It is against this backdrop that this study sought to achieve the following objectives: i) To assess the factors which inhibit women's attempt at participating in local government as elected members in the Komenda-Edina-Eguafo-Abrem Municipality, ii) To identify specific measures which enhance women's participation in local government, and iii) To make recommendations that will address the inhibitors and strengthen the enhancers to women's participation in local government.

\section{Conceptual and Theoretical Issues}

Rowe and Frewer (2004) define political participation as the mechanisms through which we facilitate "members of the public in the agenda-setting, decision-making and policy forming activities of organizations or institutions responsible for policy development." It could also be conceptualized as the process whereby all segments of the society actively involve and engage themselves in the political processes that affect their lives. Political participation, therefore goes beyond, merely voting in an election to include the ability of citizens to incorporate their views into critical decisions that shape their lives. Participation in the context of this study refers to women's ability to contest and win elections so as to influence policies and programs at both the local and national levels. The ability of women, to achieve equal participation in politics as elected officials, has become a burning governance issue that has attracted the attention of many scholars. Some of these studies are highlighted below to contextualize the present study. 


\section{PanAfrican Journal of Governance and Development, Vol. 2, No. 2, August 2021}

One of the key challenges that past researchers have often cited as a barrier to women's participation in politics is the educational gap between men and women. One body of empirical research established that this phenomenon largely accounts for women's inability to contest and win elections. The underlying theme that runs through their argument is that the illiteracy among women is high compared to men, and the formal decision-making process essentially involves writing and understanding the legal language (Cusack \& Manuh, 2009; Khan, 2006). Horowitz (2009), in her review of literature on education and women's participation in local government in India, found that women who had no formal education noted that they could have made more significant contributions to the proceedings and activities of their various local governments if they had the advantage of schooling. Other studies have also shown that women's educational attainment was less significant in predicting their presence in politics, especially in legislatures, and concluded that illiteracy should not be a barrier to women's participation in politics (Paxton $\&$ Kunovich, 2003). This raises the question of whether or not the education women need in order to participate in politics should be limited only to formal education. However, the need for formal education is more important because politics has been dislodged from the 'traditional' local settings to a formal, rational-legal setting requiring alien procedures and formalities. This is what has primarily displaced women without formal schooling from holding political office.

Many researchers have also cited gender socialization as one of the main inhibitors affecting women's ability to contest elective positions in the political sphere. Researchers who share this point of view generally argue that the differential socialization given to women and men predisposes men to the 'public' sphere and women to the 'private' sphere. The 'private' sphere implies women's domestic and nurturing work, imposing significant time constraints and workload. This disproportionate share of domestic and nurturing work that women do essentially limits their ability to engage in politics (Adu-Okoree, 2012; Akita, 2010 and Campbell, 2005). In what Akita (2010) termed gender socialization and its trappings, he contends that gender socialization in Ghana has perpetuated an entrenched notion of women's subservience, subordination, and compliance to socio-cultural ideas about the pre-eminence of men. This makes it herculean for women to navigate their way into politics in Ghana. Such hurdles appeared to be the same for women irrespective of their socio-economic statuses. 
Others also argue that contemporary politics and public decision-making tend to reflect the values and norms of men and that males generally determine the 'rules of the game' in the political arena and make politics unattractive for most women (Jayal, 2006; Ahikire, 2003). Politics, both at the local and national levels, tends to be adversarial in nature, full of character assassinations, a campaign based on the characteristics of the individual contestants and not necessarily on the developmental challenges of the citizenry. This has made many people, especially women, perceive politics as a venture that is not for very decent people. Moreover, some males have negative attitudes towards women who seek leadership positions either in corporate sectors or in politics. Such men see women who do so as having invaded a male domain. It also affects their ability to change the status quo because doing so would be interpreted as going beyond their boundaries and might elicit a backlash from the society (Akita, 2010; Broughton \& Miller, 2009). This challenge makes women's work very stressful, and in order to cope with this male-dominated environment, some women in leadership positions sometimes adopt the 'Queen Bee Syndrome.' This refers to the situation where women in top positions hardly associate with their colleagues in lower positions and discourage other women from seeking such positions (Hamel, 2009).

Many researchers also traced the source of the problem to women's inability to play active roles in decision-making at the household level (Awumbila, 2001; Greenberg \& Okani, 2001; Brown, Ekumah and Ghartey, 1996). Even though as far back as 1996, Benneh (1996) argued that structural transformations in most developing countries' economies had empowered women to get actively involved in decision-making at the household level. Awumbila (2001) explained that in most cases, women's ability to participate in decision-making at the household level is correlated with their level of education, occupation, and the amount of financial resources they contribute to family upkeep.

Women's relatively weaker financial status and its impacts on women's participation in politics have also been the focus of a considerable number of studies (UN Report on Women, 2010; Ofei-Aboagye, 2000). The inability of women to raise enough resources for campaigning has been highlighted by a number of studies as a key inhibitor to their political participation. The underlying reason for this could be attributed to certain customs and traditions within most 


\section{PanAfrican Journal of Governance and Development, Vol. 2, No. 2, August 2021}

organizations and in the dominant society. For example, women are mostly found at the lower echelons of most organizations, where salary levels are generally low.

Globally, women are paid less; their wages are 17 percent lower than those of men. Only one in four senior officials or managers is a woman (UN Report on Women, 2010). More women than men are unemployed globally and are more likely than men to be vulnerable, mainly in developing countries (ILO, 2018). It is estimated that women could increase their current levels by 76 percent if these discriminatory employment practices and wage gaps between women and men are eliminated or closed. The value of such a closed wage gap is estimated to have a global value of 17 trillion US Dollars (ActionAid, 2015).

Issues such as these have implications for women's ability to contest and win elections at both the local and national levels. Tsikata (2009) observed that the financial challenges represent one of the barriers to women's representation in politics in Ghana. Madsen's (2019) study on women in parliament in Ghana revealed that they encounter great difficulties in order to raise the money for the campaigning. Some of the Members of the Parliaments, for example, reported that they had to sell their cars and take loans in order to be able to finance their political activities. One of the female MPs reported that she did not receive any salary as an MP for eight years because her salary was used to pay for the loans she took to finance previous elections.

The Westminster Foundation for Democracy (2018) also highlighted the financial challenge as a key obstacle to women's representation in politics, although it explains that men tended to spend more money in politics than women in areas such as costs for campaigning, donations, and party workers, however, women outspend men in only one area which is media visibility and advertisement. This is understandable because the media may not naturally put a premium on making female candidates visible, so they have to put in more resources in this area.

Other researchers have examined the response to these challenges. Prominent among these studies is the role of Non-Governmental Organizations (NGOs) in promoting women's participation in politics as well as the introduction of quota systems. Chikulo (2010) argued that NGOs serve as the fulcrum around which participatory and responsive development revolves. They play a significant role in deepening the democratic decentralization in their catchment areas. This is often achieved by making people, especially marginalized groups such as women, aware of their rights and the need to get actively involved in the decentralization process and by 
lobbying the government to provide greater services. Boateng (2017) also confirmed the enormous roles these organizations play in supporting women to participate in local government as elected representatives. Horowitz (2009) observed that NGOs' training and support programs had become a major response source to the education gaps between female and male politicians.

In most cases, NGOs have sponsored candidates, trained them after the election, and helped to instill in them the virtues of accountability and responsiveness (Ofei-Aboagye, 2004; Kudva, 2003). Kudva (2003) has categorized the role of NGOs into three thematic areas; skills and confidence building, role clarification, and gender awareness. Collier (1996 cited in Chikulo, 2010) indicated that NGOs could inadvertently jeopardize the prospect of genuine development of a state by stepping into the gap between the people and the government, which discourages the people from demanding their rights from the government just because the NGOs have offered to provide some aid. Apart from this note of caution by Collier, the works of NGOs in empowering the poor and marginalized groups such as women have been a recurrent theme in the literature.

\section{The Liberal Feminist Theory}

This study was guided primarily by the liberal feminist theory. The theory has its origin in the tradition of the $16^{\text {th }}$ and $17^{\text {th }}$ centuries' liberal philosophy, which espouses principles such as equality and liberty. The basic tenet of the Liberal feminist theory is that all human beings have the potential to be rational and that all human action must pass the test of rationality. It posits that inequalities between women and men cannot be justified in rational terms (Parpart, Connelly \& Barriteau, 2000). Liberal feminists argue that an individual's sex is purely an 'accident', and as such, it should never be the basis for inequality and discrimination (Parpart et al., 2000). Advocates of this theory argue that women as a group are not allowed the same freedom or opportunity that men have; men are judged on their actual abilities and interests, while for women, their sex takes a central stage in how society evaluates them. Liberal feminists contend that the way women are treated in contemporary times violates, in one way or another, all of liberal feminism's political values, such as equality, liberty, and justice (Parpart et al., 2000).

Liberal feminists stress that women's relegation to certain works degrades them; diminishes their liberty and autonomy. Women are paid less and constitute a disproportionate share of the poor the world over. These limit their abilities to exercise their right to travel, to free expression, and 


\section{PanAfrican Journal of Governance and Development, Vol. 2, No. 2, August 2021}

their right to contest for public office because they find it difficult to finance an electoral campaign. Liberal feminists are of the view that poverty makes most women unequal to most men. To a liberal feminist, the worth of liberty is less for the poor (Jaggar, 1983).

Liberal feminists assert that most of the inequalities women suffer are not the result of discriminatory laws emanating from the legal system but from customs (Jaggar, 1983). They cited two forms of customary discrimination: first, the reluctance to appoint women to certain jobs, especially the most prestigious, well-paying, or supervisory ones, as well as the reluctance to allow women to acquire the necessary training and qualification; second, the cultural assumption that women are well-suited for some jobs such as running a home and rearing of children, and in paid labor, they are expected to work at the lowest echelons of the organization (Jaggar, 1983 in Parpart et al., 2000).

This theory generally draws a line between the private and public spheres of life. Even though there is a general debate about where exactly this line should be drawn, liberal feminists converge on the point that this line is drawn to preserve liberty. They argue that some form of regulation in the domestic sphere is needed to ensure the protection of women's safety and wellbeing (Papart et al., 2000). They further stress that women's relegation to certain types of works degrades and diminishes their liberty and autonomy (Jaggar, 1983). They also advocate for education so that customs that tend to entrench gender inequalities could be addressed. However, liberal feminists have been criticized for not being radical enough in addressing the fundamental issues of patriarchy that underlie the subordinate status of women in society.

\section{Materials and Methods}

\section{Study Area}

The Komenda-Edina-Eguafo-Abram (KEEA) Municipality is of great historical and political importance to the Central Region of Ghana. This is because this Municipality served as an entry point for the Europeans in the $15^{\text {th }}$ century. It also served as a port and a major center for the Trans-Atlantic slave trade (Abane, 2010). The Municipality covers 372.45 square kilometers. It is bordered to the northeast by Twifo-Hemang Lower Denkyira District of the Central Region, to the northwest by the Mpoho Wassa District in the Western Region, to the east by the Cape Coast district, and to the west by the Shama-Ahanta East District in the Western Region. The district is 
bordered to the south by the Gulf of Guinea. It has five traditional councils, which are Edina, Komenda, Eguafo, Abram, and Agona.

The 2010 Population and Housing Census put the population of the municipal assembly at 144,705 (69,665 males and 78, 040 females). Males represent 48.14 percent of the population in the Municipality, whereas females represent 51.86 percent. The Municipality has an average household size of four. The Municipality is largely rural since only thirty-five percent of the population live in urban areas. It is home to the Elmina Castle, the oldest castle in Africa south of the Sahara, and some beach resorts that attract many tourists from all over the world. Agriculture remains the mainstay of the Municipality's economy; eighty-five percent of the population in the Municipality is either engaged in food and cash crop production or fishing.

Figure 1: A Map of the Komenda-Edina-Eguafo-Abirem Municipality showing all settlements

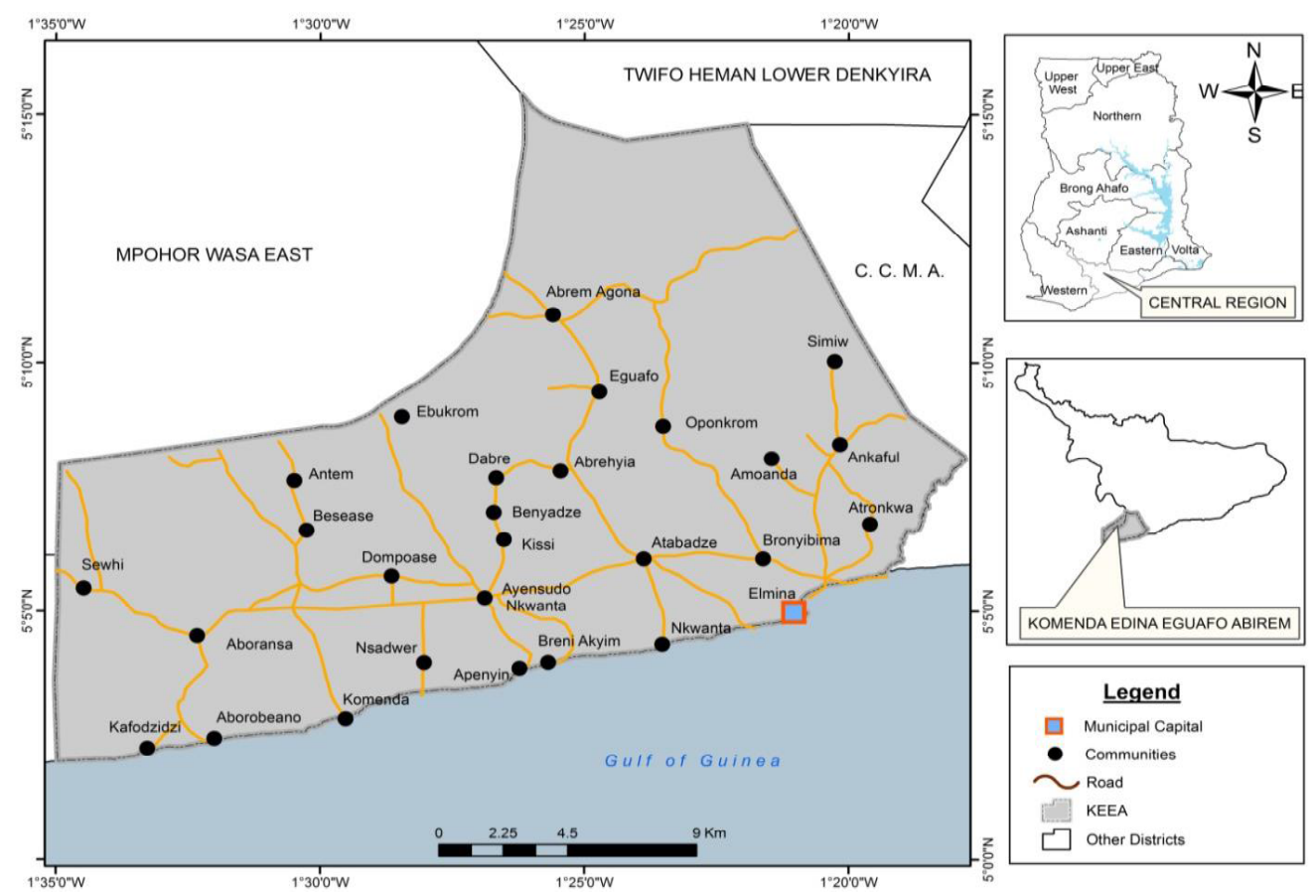

Source: Cartographic Unit, Department of Geography and Regional Planning, University of Cape Coast (2014).

\section{Data Collection}

This study adopted a purely qualitative design. It used a census of all women who had been elected as assembly women in the KEEA Municipality as research participants. There were eight such women in the study area when the data collection was carried out. These women were 


\section{PanAfrican Journal of Governance and Development, Vol. 2, No. 2, August 2021}

purposively targeted because the researcher believed that this group is in the best position to tell

precisely how women navigate their way into local government as assembly women in the study area. This decision was reached considering that these women are key stakeholders in local governance in the study area.

Besides, the study specifically targeted women who had served in the municipal assembly as elected representatives. All eight women who had served as elected assembly members until the 2015 local level elections were contacted using snowballing. The snowball technique came in handy due to the unavailability of data on past elected assembly women from the office of the Municipal Electoral Commission. The in-depth interview guides were used to elicit the subjective experiences of the assembly women in the KEEA Municipality.

The responses from the in-depth interviews were tape-recorded with the consent of respondents and transcribed. The data were qualitatively analyzed and presented using themes that emerged from the analysis. Voices that precisely captured the themes were highlighted to give glimpses into how the respondents felt about the researched issues. Pseudonyms were used in order to ensure anonymity.

\section{Results and Discussion}

\section{Financial Obstacles}

An analysis of the interview data revealed that financial difficulties were a great inhibitor to women in their desire to contest and win elections and to function successfully as assembly women in their electoral areas. All eight research participants indicated this challenge in their narrations. This financial challenge becomes more significant when one gets elected and starts working as an assemblywoman. Participants cited situations where some parents in their communities expected them to pay school fees and hospital bills for their children. They also indicated that they had to hire plastic chairs anytime they organized meetings for their communities. Some voters also expect to be remunerated for their presence when they attend meetings organized by assembly members. The views of Abena that give an idea about the financial challenges during electioneering campaigns and those that occur when they are elected as Assembly Members are presented as follows:

The financial issue is one of the major challenges for women when it comes to local politics. Everything is money; posters, campaigning - sometimes we will go somewhere 
and meet a group of people, and after the meeting when we are leaving, they will say "honorable, so are you leaving us just like that, we have to take at least some 'kooko' (Corn porridge). So if we are not well resourced, we cannot contest. Sometimes we have to go around begging people we know to help us with things such as posters. So it is a major challenge; without money, we cannot contest.

It was revealed that, on average, an elected assemblywoman spent about nine hundred Ghana Cedis on their electioneering campaigns. It is instructive to note that this money excluded other sponsorships and support most of them received from Non-Governmental Organizations (NGO's) and, in some instances, political parties. These amounts of money spent by the assembly women may seem meager, but they considered the amounts they spent were somewhat on the high side given that most of them were engaged in petty trading with very little capital. These financial challenges become more pronounced when they get elected into local government. Immediately they are elected, the electorates in their electoral areas expect them to singlehandedly bear the cost of items rented for meetings they attend. They are invited to attend funerals and naming ceremonies in the electoral areas, where they are expected to donate generously to the families that invite them. Maame, a past assemblywoman, had this to say on this challenge:

The only problem I have now is money because people approached to resolve their problems and give invitations with the expectations where money seems a prerequisite to resolving them. Sometimes, I have money in order to be able to organize people to do specific jobs in the electoral area.

The research participants also reported about contingencies fund that they need to resolve the problems as per the expectations of the community. They cited instances where they had to incur the costs of burial for unknown persons who had to be buried and instances where they had to arrange for the transportation of sick people in their electoral areas in order for them to get to higher health facilities for medical attention. Benita narrated an unforeseen incident that occurred in her electoral area that elaborates the challenge in question:

When a community problem requires money to be solved they access to us with expectation as we are assembly members. There was an instance where we found a dead person in the electoral area. The body was decomposing, so we had to see the police who 


\section{PanAfrican Journal of Governance and Development, Vol. 2, No. 2, August 2021}

permitted us to bury him. In such a situation, an Assembly member had to bear all the expenditure. Those in rural areas face many problems, so the government should give assembly members some monthly allowances to cater to such problems.

The findings presented above show that women in local government face a daunting financial challenge in their quest to contest and get elected into local government, and for those who get elected, the financial burden becomes heavier. This finding on finance is much more appreciated when it is evaluated against the fact that six of the participants were engaged in petty trading, one was working with a local $\mathrm{NGO}$, and the other was a retired nurse engaged in subsistence farming. Due to this financial burden, women are always in a dilemma about whether to invest the little money they have in local politics or use it for family upkeep. Therefore, it was not surprising that at the end of the narrative of Benyiwa, she appealed for assembly members to be paid some monthly allowances so that it could ease the financial burden on them.

It is evident that financial challenge remains one of the key inhibitors to women's participation in local government. The unanimity on the part of the research participants on the issue of funding as a constraint to their work as assembly members demonstrates the gravity of this as an inhibiting factor to women's quest to participate in local government as assembly members. The amount of money they had to spend during the electioneering campaign was on the high side, given their meager incomes. This partly stems from the fact that some voters would want the candidates to offer something either in cash or in-kind to demonstrate that they had the welfare of the communities at heart. Members of the electoral areas largely depend on them to fund certain activities in the communities. For example, in one of the communities, one of the research participants narrated how her sleep would be interrupted at midnight because a member of the electoral area was sick and needed help to hire a vehicle to convey him or her to the nearest health facility. Others also reported that anytime the community members invited them to occasions such as funerals, they were expected to make some cash donations.

These findings align with the study of Madsen 2019; the Westminster Foundation for Democracy, 2018 and Tsikata, 2009 that indicated that financial challenge is one of the most significant inhibitors to women's participation in politics. It was not surprising that some of the respondents suggested that they should be given monthly allowances in order to cushion them from the enormous financial burdens associated with their work. This support will further give 
meaning to the perceived flexibilities noted by Offei-Aboagye (2000) in the Local Government Act (ACT 462), intended to make women's participation easier. The difficulties women encounter in raising money to fund their campaign is a global one and has persisted for so long. This is due primarily to the feminization of poverty and the general wage gap between women and men, even when they engage in the same task. Indeed, the findings of the ILO (2018) that more men than women are employed and that women are more likely to be found in vulnerable employment as well as those by the UN Women Report on Women (2010) that revealed stark income inequalities between women and men provide us with a clear contextual lens to appreciate these financial inhibitions on the part of women. This fact was also acknowledged by the liberal feminist theorists who observed that discrimination based on customs and traditions has led to women relegation into the lower echelons of most organizations and is paid lower wages than men.

All these have implications for women's ability to raise the needed funding to participate in local government. As noted in Ghana, the major political parties have also initiated a policy where female parliamentary aspirants pay about one-half of the official filing fees that the parties approve for their internal party contests. Such initiatives have been taken bearing in mind the patriarchal motif of the Ghanaian and global economic structure that largely confines women to the lower levels of paid employment, thereby making them financially less capable than men to mobilize resources for purposes such as contesting an election.

\section{Unreasonably High Expectations}

Another inhibitor had to do with high expectations from community members towards assembly women. The participants explained that community members demanded more than they could offer as assembly women within their resources and power. This, according to them, was largely due to the fact that they were women, and as such, their community members expected them to display motherly compassion. This puts tremendous pressure and stress on them as representatives because the community may misconstrue failure to meet these demands to mean that they were not caring enough to get re-elected. This perhaps accounts for the difficulty that elected assembly women face in their bid to get re-elected after their first four-year tenure in the KEEA Municipality. An elected assembly member called Aba expressed the following thoughts concerning this challenge: 


\section{PanAfrican Journal of Governance and Development, Vol. 2, No. 2, August 2021}

Expectations of the community from the women assembly members are comparatively high even to manage the homely problems. To manage, I had to, by all means, get them some loans, and where I had not been able to do that, some have started saying many untruths about me. Because of this, I even called the meetings; most of the community members did not attend.

It is instructive to note that this particular assemblywoman had been in office for less than a year at the time of the in-depth interview. However, women in the community wanted her to organize them and secure loans from banks for them. She was expected to serve as a guarantor for them when she barely knew the activities they were engaged in and could not determine their creditworthiness. The women in the community felt that as a woman, she should be very responsive to their needs even within six months of assuming office. Such a demand could not possibly be met within such a time frame, and this had led to boycotts of meetings she attempted to organize.

The findings revealed that community members expect women to do so much for the electoral areas. These expectations sometimes become unreasonable when they are evaluated against the core duties of elected assembly members. Elected assembly women experience a lot of pressure and stress as a result of these high expectations from the electorates in their electoral areas. This attests to the fact that most of the challenges that assembly women in the study area encounter emanate from the societal perception of women as people who should be tender-hearted and compassionate as in the traditional role of a mother, who is expected to provide for the needs of her children whether or not she has the means. This extreme, and sometimes unreasonable pressure on elected assembly members to almost single-handedly solve the problems of their electoral areas, often compels assembly women not to contest local elections after the first fouryear tenure. These findings are in tandem with the arguments of the liberal feminist theorist that in evaluating the abilities of women and men, the sex of women often becomes the central focus, whereas men are evaluated on their actual capabilities. It is also possible that most women are not willing to contest local elections in the study area because they know about the experiences of women who had served as assembly members in the past. In the 2015 local elections, no woman was elected to the municipal assembly in the KEEA. Only one out of the three assembly 
women who were elected in the 2010 local elections in the study area contested the 2015 local elections, but she could not win for the second time.

It should be noted that these high expectations do not emanate from the promises made by the elected assembly women during their campaigns. Instead, they need to be understood from the Ghanaian cultural context; the Ghanaian culture portrays a woman in a leadership position as a mother to her people. As a result, she is expected to be sensitive and responsive to the community's needs, even when not within her power and ability. Indeed, it is not uncommon to hear electorates refer to female politicians as 'Mummy' even if the woman has a Ph.D. or bears the professorial title. From the discussions thus far, it is clear that this inhibitor has nothing to do with any discriminatory law in Ghana; it is instead the result of the gender socialization that exists within the study area in particular and the country in general. This finding is also in consonance with the arguments of the liberal feminist theory. As noted by Odame (2010), the 1992 constitution of Ghana prohibits any form of discrimination and guarantees equal rights for both women and men in all areas of their life. She explained, however, that the cultural norms of Ghanaian society do not make politics a conducive arena for women. Thus, the unreasonably high expectations are to be understood within the cultural rather than the legal context.

\section{Lack of Cooperation from Community Members}

The study revealed uncooperative attitudes of community members, including chiefs, as one of the inhibitors to women's participation in local government. Some of the assembly women cited cases where some community members vehemently opposed their moves to bring about accountability into some of the operations of the communities. Others cited chiefs and some members of the traditional authorities as being a stumbling block to their work as assembly members. Maame, a female assembly member, expressed the following views:

One of the problems I had was about accountability. The community had been selling water, and those in charge had never rendered accounts to the community. When I insisted that they should do it, it generated a whole lot of confrontations. This demand for accountability was something that the masses demanded, so it was not my decision. I received a lot of threats because of this.

Tuba also made the following remarks concerning the uncooperative attitudes of people in the electoral area as follows: 


\section{PanAfrican Journal of Governance and Development, Vol. 2, No. 2, August 2021}

When I was elected, I did not have any Unit Committee. There was no chief, it was later that the past assemblyman became the chief, and he frustrated my efforts. When I even ask the town crier to beat the gong-gong, he will order not to do so. This made the organization very difficult. So I had to go to churches to make announcements before I am able to organize meetings. When I used the public address system, the chief summoned me before the Edina 'Manhene'. That was the reason why I lost the last elections because my supporters felt too much harassment from the chief, so they asked me to quit and leave his town for him. So, when I contested for the second time, they did not even turn out to vote for me."

Women encounter hostile attitudes in their communities to perform their duties as elected representatives in their electoral areas. For some of the assembly women in KEEA, it was because of such issues that some members of their immediate families expressed reservations or opposition when they made their intentions of contesting in local elections known to them. One thing that stood out clearly in the interviewing process was that none of the assembly women's challenges (ed) in the course of their duty could be attributed to any perceived or actual incompetence on their part. They were, however, largely due to the gendered norms and values of the society in which they found themselves.

Gender socialization could also account for such challenges, which tacitly inculcates the idea that men are the 'natural' or 'ideal' leaders of society. Some often see women who attempt to challenge the status quo of the electorates and the traditional authorities as irascible. To the extent that female assembly members sometimes receive threats for demanding such simple democratic rights, revealing the kind of frustrations and stresses that they might go through in their electoral areas. These intimidations and threats from males in the electoral areas explain the patriarchal undertones, sexism, and gender bias that continue to exist in Ghanaian society. Such intimidation could make the female assembly member 'give up' or rethink her decision to seek reelection. These uncooperative attitudes were not from colleague assembly members but rather from some men who felt that women are undermining their long-held privileged position as leaders. These men practically perceive women who do so as having invaded a male domain. This resistance in the form of lack of cooperation on the part of men affects women's ability to change the status quo because doing so would be interpreted as going beyond their boundaries 
and might elicit a backlash from society (Akita, 2010). It also shows that the toxic gender socialization that seems to give men pre-eminence in almost all aspects of the Ghanaian social system is still alive and must be addressed holistically. It is not uncommon in Ghana for women who question certain practices and systems within the society to be cautioned that 'women are expected to sell garden eggs and not gun powder.' To wit, women must keep to their traditional gender roles and not cross into areas not meant for them. Women who defy these standards are treated as cantankerous women who do not know their proper place in society.

\section{Relationship with Male Assembly Members}

The assembly women in the KEEA Municipality did indicate that they had an excellent working relationship with the assemblymen and that the male assembly members had been very supportive of their work. This was one of the factors that enhanced their work as assembly women. They revealed that there had never been a period in their campaigning or as assembly members where their male colleagues gave them any problems or cause for concern. The excellent relationship they enjoyed with their male counterparts made their work much more manageable. The explanation given by Eunice summed up the relationship between female and male assembly members:

... they are all very friendly because we share views and have each other's phone numbers. If I am in need of assistance and I call them, they advise me and say do this or that; do not spend money on this leave it for the assembly, and they will do it. We all have a very cordial relationship.

The study revealed that one of the enhancers of women's participation in local government was the cordial relationship with elected men in local government. The excellent relationship between the elected male and female in local government differed from the general attitudes of males in the Municipality towards female elected representatives. This means that male assembly members in the KEEA, in particular, have probably come to terms with the fact that women must be viewed and treated as equal partners in development and politics. It could also represent an understanding of women's crucial roles in ensuring quality local governance and development in the KEEA municipality.

This finding is in sharp contrast with some of the earliest works on women's participation in local government. One of the earliest and comprehensive studies done on women's participation 


\section{PanAfrican Journal of Governance and Development, Vol. 2, No. 2, August 2021}

in local government in the Central Region by Brown, Ekumah \& Ghattey (1996) and other similar studies Ofei-Aboagye, (2000), concluded that men's attitude in the assembly made it challenging for women to work effectively. For instance, in the study of Brown, Ekumah \& Ghattey (1996), assembly women attributed their inability to function effectively partly to the attitudes of their male counterparts towards them.

However, this study revealed something to the contrary. In the present study, elected assembly women indicated that their male counterparts have been very supportive and never had any problems. This came as an unexpected finding, giving the patriarchal nature of Ghanaian society. The cordial relationship between female and male assembly persons greatly enhanced the work of female assembly members in the study area. It could be argued that perhaps the education and training programs, which were continuously organized for assembly members in the country on the need to accept women as equal development partners in the various districts, municipalities, and metropolitan assemblies, are beginning to bear fruits. This difference in attitudes towards women leaves us with no other plausible explanation than the one the author alluded to earlier

that the training given to male assembly members by NGOs might be responsible for such a change in attitudes. It also does not support the view of Broughton \& Miller (2009) and Odame (2010) that in leadership positions where men outnumber women, the men sometimes make work unnecessarily tricky for women. It does not reflect the literature wholly that politics is solely a man's arena, and their male counterparts view any woman who ventures into it as having crossed the line. This conclusion is only within the context of the relationship between female and male assembly members within the KEEA and could therefore not be generalized for other jurisdictions or fields.

\section{Participation in Household Decision-Making}

The study revealed that the majority of the assembly women have been very much involved in decision-making in their various households. For most of the time, personal involvement in decision-making at the household level helped build their confidence and impetus for their involvement in local government. Of the eight past and present assembly women interviewed, seven indicated that they were actively involved in household decision-making before joining the assembly. It was only one participant who indicated that she was never involved in decision- 
making in her household. This participant was not married and lived with her parents prior to her election into the municipal assembly. She informed:

Our family was a polygamous one. We were only living with our father and sometimes step-mothers, so our father was the major decision-maker of the house, and we did not have a say. If daddy says this or that, that is all; nobody talks.

Of the seven participants who said they were actively involved in decision-making in their various households, six of them said the confidence they derived from their active involvement in decision-making in the household motivated them to offer themselves for elections into the municipal assembly. The comment below can sum up the views:

When our family meets, and we are not present, they would not discuss anything. This is because our opinions and decisions have always helped our family members, and they accord us great respect.

The only assemblywoman who said her participation in household decision-making did not influence her to get involved in local government attributed her desire and motivation to contest to the education, encouragement, and motivation she received from a non-governmental organization that works to empower women in the study area.

Allah-Mensah's (2005) study indicated that to fully understand women's difficulties in participating in any democratic process, it was important to come down to the household level to examine the power relations that operate there. The fact that the majority of the participants indicated that they were actively involved in household decision-making and that their active participation in household decision-making gave them some level of confidence to get actively involved in local government. Women's participation in household decision-making is important if we are to boost the confidence and courage of women to get actively involved in local government in their various electoral areas as contestants. Therefore, participation in household decision-making is one of the solid foundations upon which women could be propelled to take up more significant roles in public or formal decision-making both at the local and national levels. Participation in decision-making at the household level builds women's confidence and inculcates the boldness to contest elections at the local and national levels. Women's ability to participate in decision-making at the household level serves as one of the fulcra around which their decision to participate in politics revolves. This, therefore, means that participation in 


\section{PanAfrican Journal of Governance and Development, Vol. 2, No. 2, August 2021}

decision-making at the micro-level such as those within the family has a significant influence on macro-level decision-making, such as those that occur in local government.

\section{Non-Governmental Organizations and Women's Participation}

NGOs' role in educating and empowering women to get actively involved in local government was one of the recurring themes that ran through the in-depth interviews with the assembly women. All the respondents indicated the immense roles that NGOs such as the Women in Law and Development in Africa (WiLDAF) and Christian Mothers Association have played in empowering them to be bold and assertive and contest the Municipality's local elections. These NGOs have provided training and education on public speaking, supported women with their posters, and in some rare circumstances, provided some donations in the form of cash to some female contestants. It was the view of the assembly women that the education that could empower women to participate in local government is not necessarily formal education, but rather that which the NGOs provide. As much as they did not seek to downplay the importance of formal education, they believed that what gave them the needed empowerment to contest and win such elections was the training and education provided by these NGOs. The views expressed by Benyiwa on this particular issue are narrated below:

I attended a lot of workshops that Christian Mothers and other NGOs organized. The workshops helped me acquire a lot of skills, such as how to mount the platform, speak one-on-one with electorates, do house to house campaigning, and control my temper.

The NGOs are helping the women who show interest in becoming representatives in their local government area in the study area were the Christian Mothers, WiLDAF, and the Central and Western Fishmongers Association (CEWEFIA), among others were mentioned by the research participants for the vital roles they have been playing in empowering women in the Municipality. NGOs' role in training women who show interest in local government was a significant enhancer of women's participation in local government.

This finding showed the important roles that NGOs play in enhancing women's participation in politics. All the research participants had received some training from NGOs on how to conduct their campaigns, the art of public speaking, and the rudiments of the political decision-making process. These training often took the form of workshops before and after the local elections. The training and support essentially filled the gap in political knowledge between males and 
females and placed women at a level where they could compete favorably with their male counterparts. One of the participants revealed that although she was not part of any decisionmaking at her household, it was an NGO in the study area that provided her with the proper education and empowerment in order for her even to dare to contest elections. There was also an instance where one of the participants indicated she was in her early twenties and had never dreamt of becoming an assembly member. However, the NGO identified her potential and empowered her to contest, winning against her male contender.

The finding is in line with studies by Boateng, 2017; Chikulo, 2010; Horowitz, 2009; OfeiAboagye, 2004; Kudva, 2003, all emphasized the NGOs play in promoting women's empowerment and participation in local government. It also fits into Kudva's (2003) categorization of the role of NGOs in promoting women's participation in local governance, namely skills and confidence building, role clarification, and helping women to appreciate gender relations and their implications for their candidacy (Gender Awareness). The findings on NGOs and their role in enhancing women's participation in local government appear to suggest that the NGOs are operating in tandem with one of the key proposals of the liberal feminists on how to end women's subordination in society, which is education. For liberal feminists, it is through education that the age-old customs and discriminatory practices that are inimical to the advancement of women in all spheres of life can be addressed. The findings are also in keeping with the observation by Horowitz (2009) that the training and support programs of NGOs constitute a significant source of response to the education gaps between female and male politicians.

\section{Conclusions and Recommendations}

This study sought to assess the factors that enhance and hinder women's participation in local government. The prominent inhibiting factors were financial constraints, unreasonably high

expectations, and uncooperative attitudes of community members. The most significant factors that enhanced women's participation in local government were women's active involvement in decision-making at the household level, the education, training, empowerment, support programs by NGOs, and a good working relationship with male assembly members.

It could be concluded that the challenges women face in their quest to participate in local government as elected representatives do not emanate from deliberate laws but the result of long- 


\section{PanAfrican Journal of Governance and Development, Vol. 2, No. 2, August 2021}

held customs and beliefs about the proper roles of women in society. This is in keeping with the arguments of the liberal feminist theory. It appears the inhibitors to women's participation have remained static, and unless firm decisions are taken to address them once and for all, they will continue to linger over. However, in the midst of these daunting inhibitors, other women have been able to navigate their ways into the corridors of political power and have shared their enhancing factors with us. While we await a period where these inhibitors will be addressed using principles of equity, women who aspire to be elected into local government must take advantage of the available enhancers. This study, therefore, recommended the following in order to improve on women's participation in politics at the local level:

$>$ The National Commission for Civic Education, educational institutions, faith-based organizations, and NGOs should educate the citizenry on the importance of women's representation in politics both at the local and national levels.

$>$ The state and other international donors should support NGOs that work to empower women politically.

$>$ The state or the local government should ensure that elected representatives in local government are paid either salaries or allowances monthly to ameliorate the enormous financial challenges they are confronted with.

$>$ Parents, households, and lineage heads should consciously involve and encourage their girls and boys to participate in household decision-making.

\section{References}

Abane, A. M. (2010). Background characteristics and accident risk of commercial vehicle drivers in Cape Coast-Elmina area of the central region of Ghana. Oguaa Journal of Social Sciences 5(1): 64-86.

Adu-Okoree, B. I. (2012). Enhancing women's household reproductive roles through microfinance: A study of women traders in Tema. International Journal of Academic Research in Business and Social Sciences 2(6):261-272.

Ahikire, J. (2003). Gender equity and local democracy in contemporary Uganda: Addressing the challenge of women's political effectiveness in local government. In Goetz A. M., Hassim S. (eds.). No shortcuts to power: African women in politics and policymaking. London and New York: Zed Books, pp. 213-39.

Akita, E. (2010). Hegemony, Patriarchy and Human Rights: The Representation of Ghanaian Women in Politics. (Electronic Thesis or Dissertation).https://etd.OhioLINK.edu/ (Accessed 29 December 2020).

Allah-Mensah, B. (2005). Women in politics and public life in Ghana. Accra: Friedrich-Ebert Foundation. 
Awumbila, M. ((2001). Women and gender equality in Ghana: a situational analysis. In Tsikata D.(ed.). Gender training in Ghana: Politics, issues and tools. Accra: Worli Publishing Service, pp.33-59.

Boateng, J.S. (2017). Women in District Assemblies in Ghana: Gender construction, resistance and empowerment (Unpublished doctoral dissertation Edith Cowan University, Western Australia). Retrieved from HTTPS:// ro.ecu.edu.au/theses/2048.

Boateng, J.S. \& Kosi, I. (2015). Women's representation and participation in District Assemblies in Ghana: Analysis of supply-side and demand-side framework. International Journal of Scientific and Research Publications 5(10): 1-6.

Benneh, G. (1996, December 14-18). Keynote address on family and development, delivered at the research and training workshop on family held at school of administration, university of Ghana, Legon.

Broughton, A., \& Miller, L. (2009). Women in senior management: Is the glass ceiling still intact?' ISGUC: The Journal of Industrial Relations \& Human Resources 11(4): 7-23. DOI:10.4026/1303-2860.2009.0122.x.

Brown, C.K., Ghartey, N.K.T., \& Ekuma, E.K. (1996) Women in local government in Ghana: A case study of central region. Accra: Freidrich Ebert Foundation.

Chikulo, B. (2010). Democratic local governance in Southern Africa Development Community region: Some emerging issues and challenges. Commonwealth Journal of Local Governance 5: 145-157. DOI.org/10.5130/cjlg.voi5.1479.

Cusack, K. \& Manuh, T. (eds.) (2009). The architecture for violence against women in Ghana, Accra: Ghana Gender Studies and Human Rights Documentation.

European Union (2013). Women and men in leadership positions in the European Union 2013: A review of the situation and recent progress. European Commission- Directorate-General for Justice DOI: 10.2838/50821.

Ghana Statistical Service (2012). 2010 Population and Housing Census: Final Results. Accra, Ghana: Ghana Statistical Service.

Hamel, S. (2009). Exit, voice, and sense-making following psychological contract violations. Journal of Business Communication, 46(2): 234-261.

Horowitz, K. (2009). Getting good government for women: A literature review. Agriculture and Rural Development Discussion Paper 43, The World Bank.

International Labour Organization (2018). World employment and social outlook: Trends for women 2018 Global Snapshot. International Labour Office-Geneva https://www.ilo.org/wcmsp5/groups/public/-dgreports/-dcomm/pub1/documents/ publication/ wcms_619577.pdf(Accessed on 12 November, 2020).

Inter-Parliamentary Union and UN Women (2015). Women in politics: Situation on 1 January 2015. http://www.unwomen.org/ /media/headquarters/attachments/ sections/news/stories/2015/femmesenpolitique_2015_web_anglais.pdf (Accessed on 20 November, 2020).

Jaggar, A.M. (1983). Feminist politics and human nature. Lanham: Rowman and Littlefield Publishers.

Jayal, N. G. (2006). Engendering local democracy: The impact of quotas for women in India's panchayats. Democratization 13: 15-35.

Kudva, N. (2003). Engineering Elections: The experiences of women in the Panchayati Raj in Karnataka, India. International Journal of Politics, Culture and Society 16: 445-63.

Madsen, D. H. (2019). Gender, power and institutional change: The role of formal and informal 


\section{PanAfrican Journal of Governance and Development, Vol. 2, No. 2, August 2021}

institutions in promoting women's political representation in Ghana. Journal of Asian and African Studies 54(1): 70-87. DOI: 10.1177/0021909618787851.

Nwagbara, U. (2009). Changing Canon: Chinua Achebe's women, the public sphere and the politics of inclusion in Nigeria. The journal of pan African, 3(3): 3-22.

Odame, F.S. (2010). Women in politics in Ghana: A study on local government in the Greater Accra Region. Ghana Journal of Development Studies 7(1): DOI: 10.4314/gjds.v7i1.61401

Ofei-Aboagye, E. (2000). Promoting women's participation in local governance and development: the case of Ghana. Accra: Institute of Local Government Studies.

Ofei-Aboagye, E. (2004). Promoting gender sensitivity in local governance in Ghana. Development in practice 14:753-60.

Parpart, J.L., Connelly, M.P., \& Barriteau, V.E. (eds.) (2000). Theoretical perspectives on gender and development. Ottawa: International Development Research Centre.

Paxton, P., \& Kunovich, S. (2003). Women's political representation: The importance of ideology. Social Forces 82: 87-114.

Rowe, G. and Frewer, L. J. (2004). Evaluating public-participation exercises: A research agenda. Science, Technology and Human Values, 29 (4): 512-556.

Schwanke, D. (2013). Barriers for Women to Positions of Power: How Societal and Corporate Structures, Perceptions of Leadership and Discrimination Restrict Women's Advancement to Authority. Earth Common Journal 3(2): 15-28. DOI: 10.31542/j.ecj.125

Tamale, S. (1999). When hens begin to grow: Gender and parliamentary politics in Uganda. Boulder Colorado, USA: Westview Press.

United Nations Report on Women (2010) UN Women: Facts and figures on women worldwide. http://www.unwomen.org/wp-content/uploads/2010/06/UNWomenFactsAndFiguresOnWomen-20100702.pdf (Accessed on 4 April, 2019).

Westminster Foundation for Democracy (2018). The costs of politics in Ghana. http://www.wfd.org (Accessed on 24 June, 2021). 